第56巻第 3 号岩石鉱物鉱床学会誌 1966 年 9 月 5 日 研究報文

\title{
A NICKELIFEROUS SEPIOLITE FROM THE ŌEYAMA NICKEL MINE, KYOTO PREFECTURE, JAPAN
}

\author{
Masatomo Muchi \\ Fuknoka University of Education \\ Yoshiaki Hoshino and Isao Furusato \\ Kurosaki Ceramis Co. Ltd.
}

\begin{abstract}
The light green mineral from the Oeyama nickel mine has been identified to be nickeliferous sepiolite being a very rare mineral by means of chemical analysis, electron micrographs, thermal curves and $\mathrm{x}$-ray diffraction. Its occurrence seems to be the first recorded in Japan. The mineralogical properties generally agree with those of fibrous type sepiolites described in the literatures, but the thermal effects on this mineral are somewhat different from those on the fibrous type. From the electron micrographs and X-ray analyses, it has been confirmed that the Oeyama nickeliferous sepiolite is composed of fibrous particles which are not uniform in length and have higher crystallinity than that of the sepiolite from this mine described recently. The chemical formula for this mineral was $12 \mathrm{SiO}_{2} \cdot 8(\mathrm{Ni}, \mathrm{Fe}, \mathrm{Mg}) \mathrm{O} \cdot 17 \mathrm{H}_{2} \mathrm{O}$. Of this $17 \mathrm{H}_{2} \mathrm{O}$ obtained from the chemical analysis $3 \mathrm{H}_{2} \mathrm{O}$ were considered to be possibly hygroscopic water in comparison with the Preisinger formula.
\end{abstract}

\section{INTRODUCTION}

Peridotite and serpentine rock fragments with various sizes have deposited stepwise at the foot of the cliff on the northeastern side of Akaishi-dake (the chief peak of the Oeyama mountains). The weathering of these accumulations which formed the piedmont upland has considerably proceeded, and in the consequence, a lateritic appearance has well been displayed by dark- and red-brown soil or clay materials formed at or near the surface.

Kinoshita and Takimoto (1939) described that beneath the reddish brown clay, the so-called "blue caly" tinged with green

(Manuscript received, May 30, 1966) 
usually occurred with somewhat clear loundary below the ground water table, and that the partially weathered serpentine fragments were intermingled with such clays. And also they confirmed that the upper part of the reddish brown clay included a very little amount of nickel, because it was leached out by rain water with soluble materials, while, in the "blue clay" and intermingled parts, the nickel content remarkably increased; and designated such nickelbearing sub-soil and clayey materials as "caly nickel ore" (composed essentially of nickel serpentine and nickel chlorite).

One of the authors happened to find the small fragments of light greenish clay resembling with usual garnierite in appearance in highly weathered debris accumulating on the southeastern side of this mine, and the sample is shown in Fig. 1. This clay accompanies deep greenish clay material on its outer side. The work of this clay material will be published later. It has been confirmed that the light greenish clay is not composed of garnierite, but of nickeliferous sepiolite. Nickeliferous sepiolite is a very rare mineral in the world, there being only one occurrence at New Caledonia, which is described by Caillere (1936) till now.

Therefore, the occurrence of nickeliferous sepiolite from this mine is very noticeable. The origin of this mineral would be due to the reaction between serpentine and descending water with dissolved salts.

The density measured by using the heavy liquid (a mixture of bromoform and bromobenzene) was about 2.15 to 2.20 . In thin section the fibrous particles have straight extinction and a moderate index of $n=1.55-1.56$.

\section{Chemical Axalysis}

The result of chemical analysis of the Ōeyama nickeliferous sepiolite is given in Table 1 with those of the nickeliferous sepiolite from New Caledonia and the fibrous type sepiolite from Ampandrandava. The magnesia content of this nickeliferous sepiolite is a little lower and also the $\mathrm{H}_{2} \mathrm{O}$ is a little higher, in comparison with those of the New Caledonia one. The water content, particularly $\mathrm{H}_{2} \mathrm{O}$ (-) content, considerably fluctuates among specimens as shown in the literature. Many problems for the fluctuating water have yet been left unproved, although the fluctuation is thought to be caused, to some extent, by the variation of the degrees of crystallinity or the quantitative difference of the two type sepiolites (fibrous and compact type ones) included in each specimen even if the specimen 

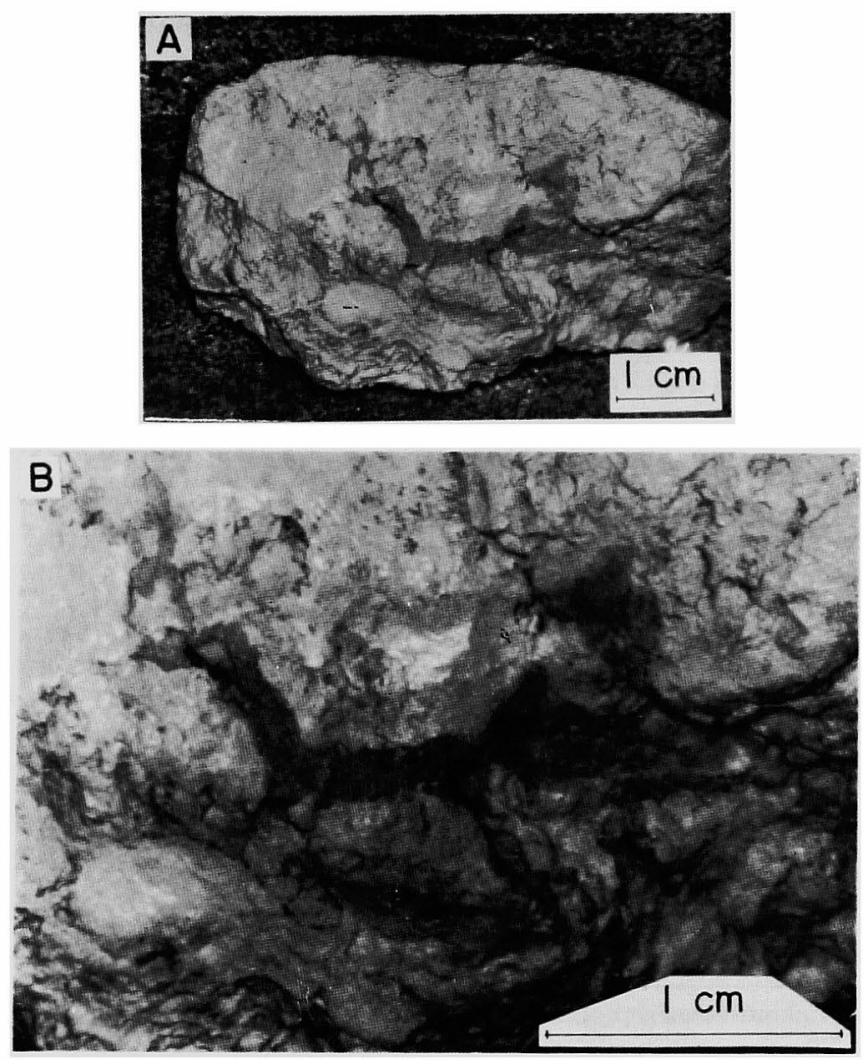

Fig. 1. (A) The general view of the light greenish clay composed of nickeliferous sepiolite.

(B) The detailed view of the central portion of (A).

is pure, as shown later on.

The chemical analysis of this specimen indicates a ratio of $\mathrm{SiO}_{2}: \mathrm{MgO}: \mathrm{H}_{2} \mathrm{O}=3: 1.998: 4.191$ as shown in Table 1 . The ratio $\mathrm{SiO}_{2} / \mathrm{MgO}$ of this specimen closely agrees with those of usual sepiolites in the literature, and its chemical formula is shown as follows: $12 \quad \mathrm{SiO}_{2} \cdot 8$ octahedral metal oxides $\cdot 17 \mathrm{H}_{2} \mathrm{O}$.

Nagy and Bradley (1955), and Presinger (1959) postulated the idealized chemical formula of sepiolite to be $12 \mathrm{SiO}_{2} \cdot 8 \mathrm{MgO} \cdot 14 \mathrm{H}_{2} \mathrm{O}$, but there are differences between the numbers of water molecules belonging to the structure respectively. Of the seventeen water molecules obtained by the chemical analysis, about three of them 
are considered to be hygroscopic water. Assuming that 32 oxygens are included in the half-unit cell of sepiolite, the structural formula is given as follows:

$$
\left(\mathrm{Si}_{11.95} \mathrm{Al}_{0.05}\right)\left(\mathrm{Fe}_{0.03} \mathrm{Ni}_{0.91} \mathrm{Mg}_{7.06}\right) \mathrm{O}_{32}
$$

Table 1. Chemical compositions of nickeliferous sepiolites from the Oeyama nickel mine and from New Caledonia, and the fibrous type sepiolite from Ampandrandava, Madagascar, after $\mathrm{S}$. Caillere

\begin{tabular}{|c|c|c|c|c|}
\hline & \multicolumn{2}{|c|}{$\begin{array}{l}\text { Nickeliferous sepiolite from } \\
\text { the Öeyama nickel mine, } \\
\text { Kyoto Prefecture }\end{array}$} & \multicolumn{2}{|c|}{$\begin{array}{l}\text { Nickeliferous sepiolite from } \\
\text { New Caledonia and fibrous } \\
\text { type sepiolite from Ampan- } \\
\text { drandava, Madagascar, } \\
\text { after S. Caillere }\end{array}$} \\
\hline & $w t 96$ & $\begin{array}{r}\text { Molecule ratio } \\
\times 1000\end{array}$ & (1) wt\% & (2) wtor \\
\hline $\begin{array}{l}\mathrm{SiO}_{2} \\
\mathrm{Al}_{2} \mathrm{O}_{3} \\
\mathrm{Fe}_{2} \mathrm{O}_{3} \\
\mathrm{FeO} \\
\mathrm{MgO} \\
\mathrm{CaO} \\
\mathrm{NiO} \\
\mathrm{Na}_{2} \mathrm{O} \\
\mathrm{K}_{2} \mathrm{O} \\
\mathrm{H}_{2} \mathrm{O}(+) \\
\mathrm{H}_{2} \mathrm{O}(-)\end{array}$ & $\begin{array}{r}50.48 \\
0.34 \\
0.28 \\
20.03 \\
\text { trace } \\
7.60 \\
0.11 \\
0.06 \\
9.71 \\
11.50\end{array}$ & $\left.\begin{array}{r}841 \\
2\end{array}\right\} \mathrm{SiO}_{2}$ & $\begin{array}{r}50.40 \\
0.73 \\
20.28 \\
9.70\end{array}$ & $\begin{array}{r}52.50 \\
0.60 \\
2.90 \\
0.70 \\
21.31 \\
0.47\end{array}$ \\
\hline Total & 100.11 & & 99.79 & 99.75 \\
\hline
\end{tabular}

(1) Nickeliferous sepiolite from New Caledonia (S. Caillere).

(2) Fibrous type sepiolite from Ampandrandava, Madagascar (").

*: Octahedral metal oxides.

\section{Electron Micrographs}

The electron micrographs of this specimen are shown in Fig. 2. From the observation under a polarization microscope or electron microscope, it is recognized that sepiolite particles can be generally classified into two types. The one is fibrous, tubular and rod-like, being designated as alpha-sepiolite or para-sepiolite (Fersman 1908, quoted by Davis 1951). The other is flake-like, spherical and irregular, being considered to be amorphous, and it is called beta-sepiolite by Winchell (1951) and Davis (1951).

Under the highly magnified electron microscope, this specimen seems to be composed of poorly developed fibers on the whole, and somewhat rounded flaky particles are also observed. It may be 
characteristic that the two types occur together in this specimen. The pictures well display that the individual tubes considerably vary in length and width, and the small particles in Fig. $2 \mathrm{D}$ reveal the rather stubby nature. Some long bundles are surrounded by considerably shorter tubes which may be due in part to breakage caused by the heat of the electron beam.

A few cross sections are clearly observed at terminations of tubes, indicating somewhat angular or polygonal forms besides circular ones. Some tubes have fuzzy material on both outside and inside and such forms appear to be cylindrical rather than lath-like. Similar material is frequently observed on chrysotile and halloysite particles. The width obtained from the measurement on 220 tubes in the pictures ranges from 0.01 to 0.05 microns with the mean value of 0.03 microns. This value is considerably smaller than the mean width of hydrated-halloysite particles measured by Bates, Hildebrand and Swineford, $1950(860 \AA)$, but is more similar to the average of outside diameters of chrysotile particles measured by Bates and Comer, 1959 (250Ä).

These particles yield the longitudinal striations parallel to the length of the fiber, as frequently seen for alpha-sepiolites and other tubular minerals. And also tubes interlace with irregularly-shaped particles having fine projections or "amorphous appearing material" as observed on the poorly-crystallized sepiolite particles from this mine described by authors (1965).

\section{Thermobalance Curve and Differential Thermal Analysis Curve}

The thermogravimetric analysis for this specimen was carried out for about 0.2 grams, using the Honda thermobalance apparatus; and the record was obtained by the periodical reading at intervals of approximately one minute. The sample was heated from room temperature to $1000^{\circ} \mathrm{C}$ at a heating rate of $5^{\circ} \mathrm{C}$ per minute. The curve is shown in Fig. 3.

The water in this specimen is dehydrated in four temperature regions with considerably steep inflections as indistinctly seen on this curve, such a loss often appearing on those of fibrous type sepiolities, but it is not clear in general. This thermobalance curve is similar to those of the nickeliferous sepiolite and fibrous type material published by Caillere and Henin (1957), mostly resembling the curve having four regions of water loss for the Vallecas sepiolite worked by Martin-Vivaldi and Cano-Ruiz (1956). However, 
on the curve of the Vallecas sepiolite the temperature commencing the dehydration in the third region from the low temperature side is rather lower than that of this specimen, and on the curve of the New Caledonia nickeliferous sepiolite, the temperature beginning the second inflection is more higher, and the third inflection is not

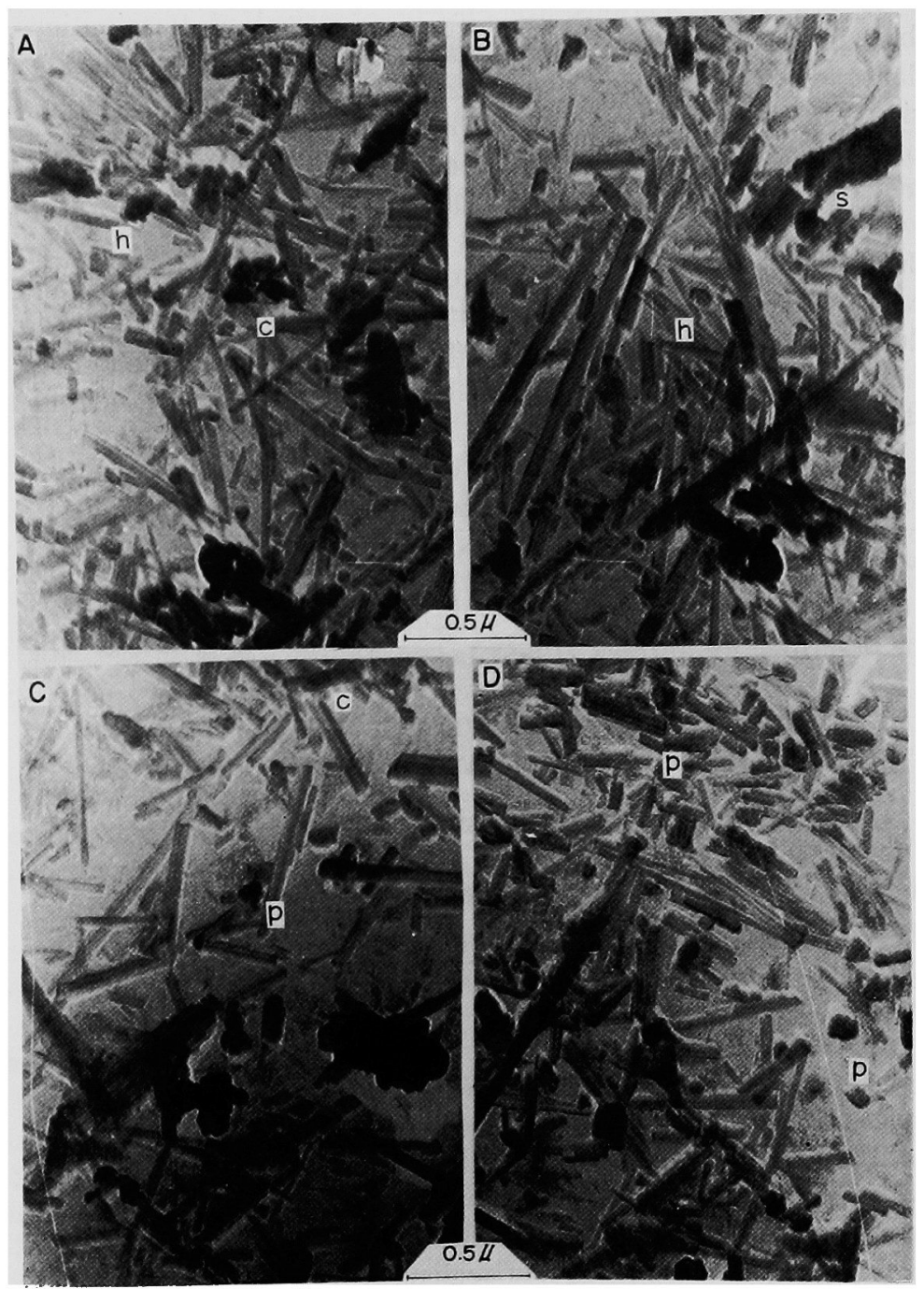

Fig. 2. 
so remarkable. On this thermobalance curve, a weight loss of about thirteen per cent which would seem to be due to adsorbed and zeolitic water simultaneously occurs between room temperature and $250^{\circ} \mathrm{C}$. And then in the second stage, the relatively quick loss of about four per cent follows in the $250^{\circ}-450^{\circ} \mathrm{C}$ region, and the following cliff displaying a weight loss of about seventeen per cent clearly appears in the region of $450^{\circ}-650^{\circ} \mathrm{C}$, being sharp and characteristic for this specimen, although the cliff in this temperature region is generally small and not distinct as shown in the literature. The water loss of two types subdivided in the region of $250^{\circ}-650^{\circ} \mathrm{C}$, corresponding to the bound water, total 5.7 per cent against the loss of $\mathbf{5 . 5}$ per cent expected from the Bauner-Preisinger model. Above $650^{\circ} \mathrm{C}$, the final dehydration slowly begins at first, then suddenly at $750^{\circ} \mathrm{C}$, and again slowly above $900^{\circ} \mathrm{C}$. The weight loss in this temperature region is about 2.5 per cent comparable to the one of 2.7 per cent expected from the model.

The differential thermal analysis curve of this specimen is shown in Fig. 4. The curve was obtained by using the Shimazu D.T.A. apparatus and the sensivity was adjusted to give $12 \mathrm{mV}$ and $100 \mathrm{uV}$ to $\mathrm{X}$ - and $\mathrm{Y}$-axis respectively. The heating rate was approximately $10^{\circ} \mathrm{C}$ per minute. Although this curve is rather different from that of the New Caledonia nickeliferous sepiolite as shown later on, this exhibits certain similarities to those of the fibrous type sepiolites. The first endothermic effect is very remarkable and forms two peaks at $130^{\circ}$ and $150^{\circ} \mathrm{C}$. The fibrous type sepiolites often show this double peak. Between $250^{\circ}$ and $450^{\circ} \mathrm{C}$, no remarkable endothermic

Fig. 2. Electron micrographs of nickeliferous sepiolite from the Ōeyama Nickel Mine.

$A$ and $B$ : These pictures show long tubes and bundles of elongated fibers surrounded by much shorter ones which may occur as the result of breakage. The longitudinal striations parallel along the lengths of the fibers well develop. A large subhedral lath is observed at the upper left in the (B) figure.

$h$ : Hexagonal cross section.

c: Tubes and laths with circular terminations.

s: Subhedral lath.

$\mathrm{C}$ and $\mathrm{D}$ : These pictures are characterized by considerably short, rather flaky particles associated with long tubes.

Polygonal and circular cross sections are often seen, and partial unrolling is observed at the lower right in the (C) figure.

p: Polygonal cross section.

c: Circular cross section. 
peak is recognized but replaced by a dome-like exothermic peak which gives a flattened culmination in the region of $295^{\circ}$ and $405^{\circ} \mathrm{C}$, though the fibrous sepiolite from Ampandrandava shows a small endothermic peak in this temperature region as described by Caillere and Henin (1957). Thereafter a weak and gently-elongated endothermic peak proceeds to about $600^{\circ} \mathrm{C}$, it being negligible, but

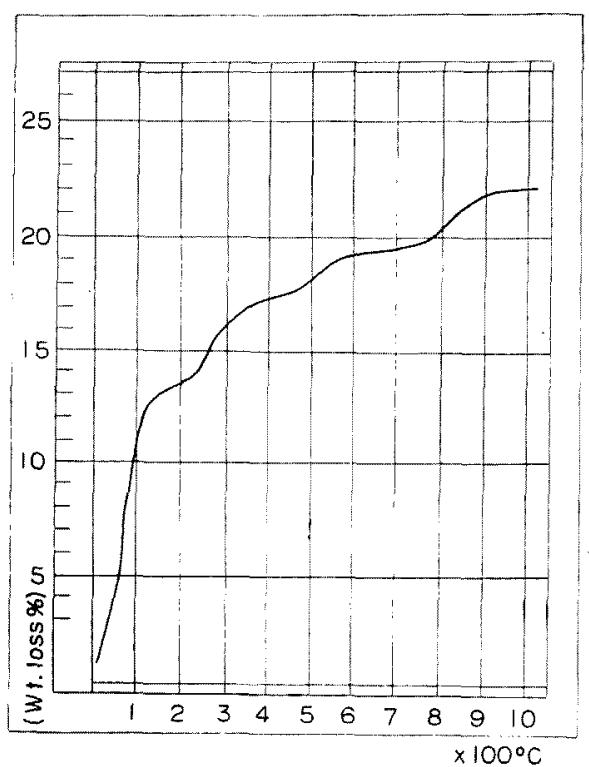

Fig. 3. Thermobalance curve for the Ōeyama nickeliferous sepiolite.

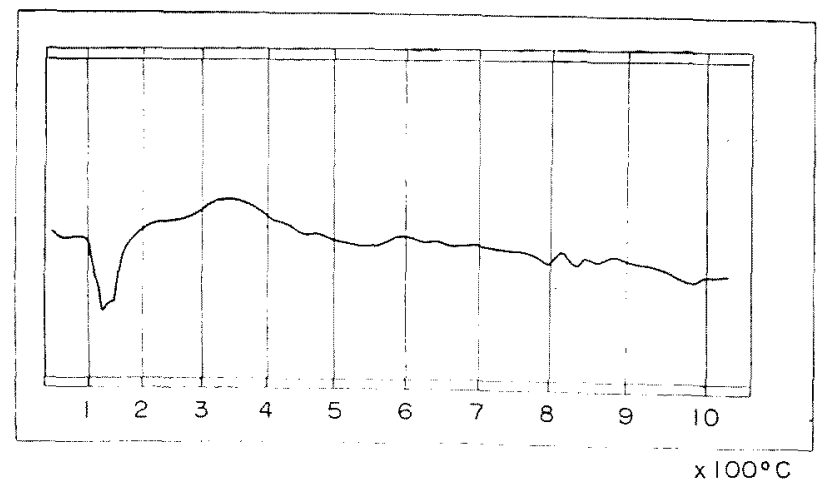

Fig. 4. Differential thermal analysis curve for the Ōeyama nickeliferous sepiolite. 
the New Caledonia material exhibits a clear and large endothermic peak at the same temperature. The high temperature endothermic effect commences at $750^{\circ} \mathrm{C}$, giving the peak culmination at $790^{\circ} \mathrm{C}$, and its peak is small and gradually going down toward the high temperature side. This peak is immediately followed by a small exothermic peak which is rather broadened. This weak endothermicexothermic inversion appears on the curve between $795^{\circ}$ and $815^{\circ} \mathrm{C}$, being not much sharp as compared with those of some fibrous type sepiolites. The sharpness of this inversion may be considered to be rather pronounced for the compact type sepiolites than the fibrous type ones, as well given by the Ampandrandava sepiolite (compact type) and the poorly crystallized one from this mine. Finally a small endothermic peak with the peak temperature of $825^{\circ} \mathrm{C}$ closely follows to the inversion and the peak is clearly seen for the New Caledonia nickeliferous sepiolite only in the literature, although the characteristic endothermic peak preceding an exothermic one has not been recognized for that sepiolite.

It is very hard to interpret the co-relation between the thermobalance and differential thermal analysis curves for this nickeliferous sepiolite with precision, for the dehydration processes have not been understood definitely yet.

\section{X-RAY SPECTROGRAMS}

The X-ray spectrograms of crude and heated specimens were

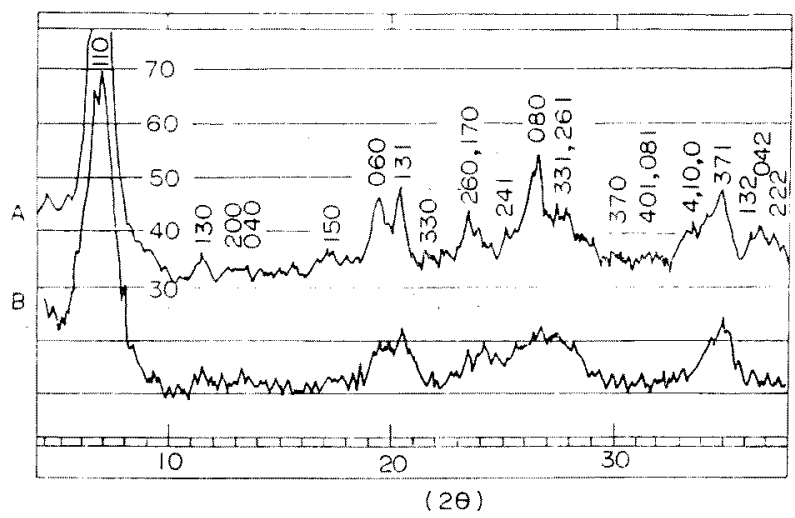

Fig. 5. X-ray spectrograms of sepiolites from the Ōeyama nickel mine.

A: Nickeliferous sepiolite.

B: Poorly-crystallized sepiolite. 


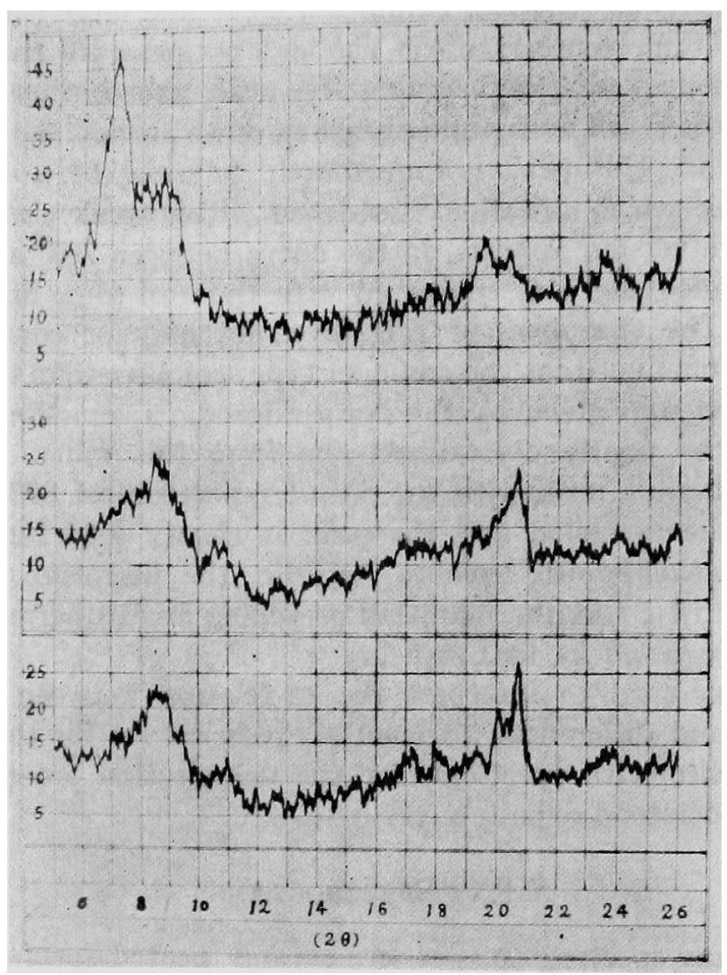

Fig. 6. Effects of heating on some of characteristic reflections from the Ōeyama nickeliferous sepiolite.
A: Heated at $400^{\circ} \mathrm{C}$ for one hour.
B: Heated at $600^{\circ} \mathrm{C}$ for one hour.
$\mathrm{C}$ : Heated at $700^{\circ} \mathrm{C}$ for one hour.

obtained with a geiger counter X-ray diffractometer. Filtered copper radiation ( $\mathrm{Cu} \mathrm{K} \alpha$ : $1.418 \AA$ ) was used under the following experimental conditions: $35 \mathrm{kV}, 15 \mathrm{~mA}$, scale factor: 8 , multiplier: 1 , time constant: 4 seconds, scanning speed $2^{\circ}$ per minute.

The spectrograms of crude and heated specimens are shown in Figs. 5 and 6, and observed intensities and measured spacings from the spectrograms are listed in Table 2 together with the data for the Little Cottonwood sepiolite by Brindley (1959).

The X-ray data clearly indicate that this specimen is almost pure, because the diffraction peaks extranteous to sepiolite are not 
obstrved. Generally the diffraction peaks from this specimen are sharper and more resolvable than those of the Eski Chehir and the Ōeyama sepiolites, but are not so well resolved as those of the Little Cottonwood one. Some peaks such as $2.68 \AA, 2.61 \AA, 2.06 \AA$ and 2.04 $\dot{A}$ are somewhat broader.

The thermal behaviours on this specimen generally agree with those mentioned by Caillere and Henin (1961), however some discrepancies have been observed on the spectrograms. Namely, the broad peak with medium intensity appears in the region of $11-9 \AA(2 \theta)$ when heated at $400^{\circ} \mathrm{C}$ for one hour, it giving the culminations at about $10.6 \AA$ and $9.9 \AA$; and on the other hand, the intesity of the $7.5 \AA$ peak does not increase, notwithstanding that the enhancement of its peak has been indicated by Cailler and Henin (1961). After heating at $700^{\circ} \mathrm{C}$ for one hour, the intensity of the diffused $12 \AA$ peak remarkably decreased, and the $10.6 \AA$ peak shifted to $9.9 \AA$. Also a new peak clearly appeared at about $9.3 \AA$ and the intensity was relatively weak. Such a sepiolite anhydride commenced its structural change at $400^{\circ} \mathrm{C}$ seemed to probably persist up to $700^{\circ} \mathrm{C}$, and the diffraction peaks from this specimen disappeared completely at about $850^{\circ} \mathrm{C}$. Such changes on the $\mathrm{X}$-ray spectrograms were noticeably different from those of the Ōeyama sepiolite.

\section{Conclusion}

Light greenish clay mineral found from the Oeyama nickel mine was identified as a nickeliferous sepiolite by means of chemical analysis, differential thermal analysis, thermogravimetry, electron micrographs and X-ray diffraction. This mineral seems to be very much valuable in its occurrence in this location. The mineralogical properties are summarized as follows:

(1) The $\mathrm{H}_{2} \mathrm{O}(-)$ content is somewhat higher than those of other fibrous type sepiolites, and of $17 \mathrm{H}_{2} \mathrm{O}$ obtained from the chemical analysis $3 \mathrm{H}_{2} \mathrm{O}$ is considered to be adsorptive. The structural formula for this specimen is postulated as

$$
\left(\mathrm{Si}_{11.9} \mathrm{Al}_{0.05}\right)\left(\mathrm{Fe}_{0.03} \mathrm{Ni}_{0.91} \mathrm{Mg}_{7.06}\right) \mathrm{O}_{32} \text {. }
$$

(2) In the electron micrographs, the particles of this nickeliferous sepiolite are composed of a mixture of two types of material: the one is fibrous, and the width of fibers ranges from 0.01 to 0.05 microns, taking up the greater part of particles in general; and the other is flake-like and irregular in outline, being interstitial, and seems to be composed of aggregates of very fine or amorphous material. 
Table 2. X-ray powder data for the Oeyama, nickeliferous sepiolite and the fibrous type sepiolite from Little Cottonwood (Brindley, 1959).

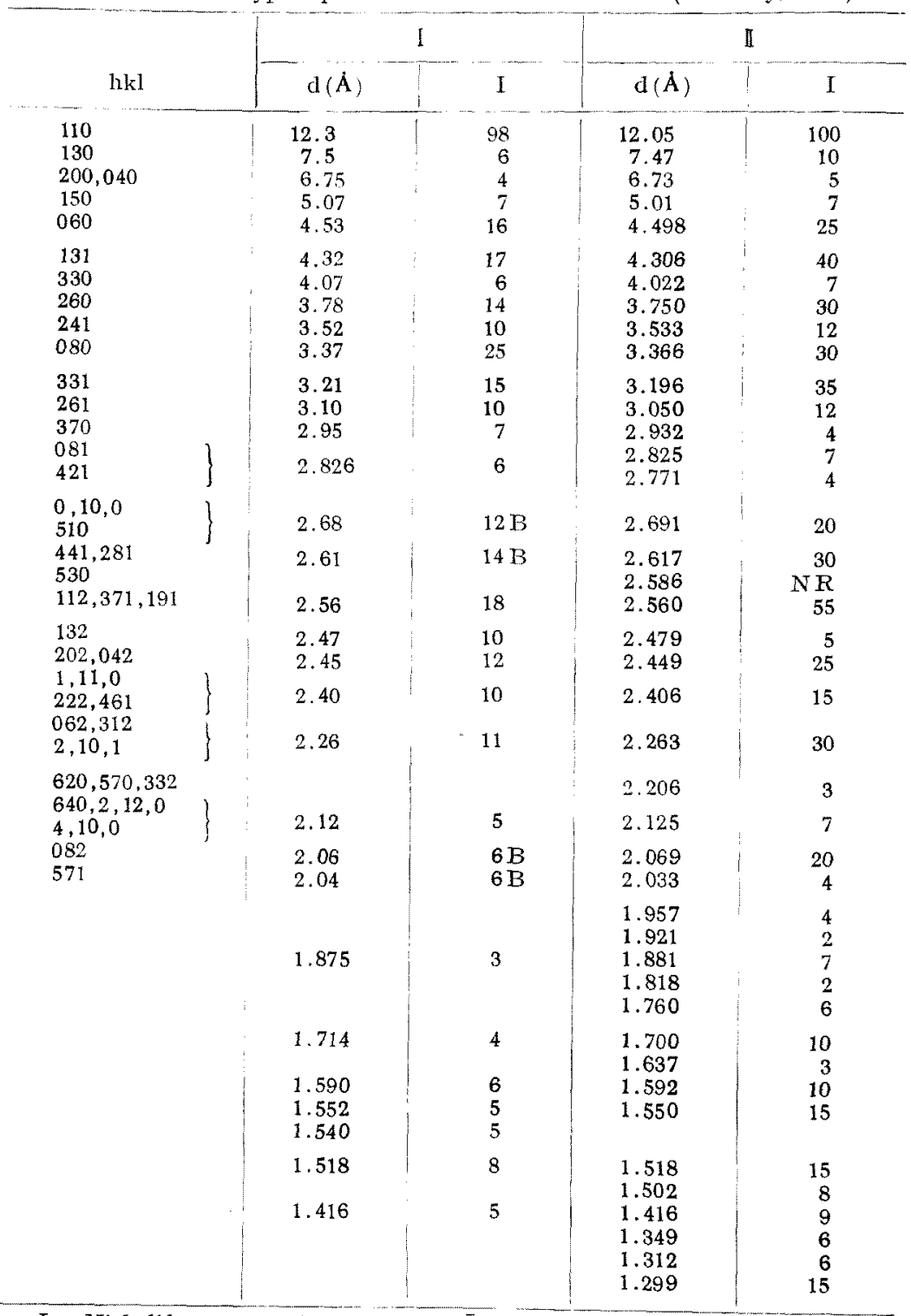

I: Nickeliferous sepiolite from the Ōeyama nickel mine.

II: Fibrous type sepiolite from Little Cottonwood, Utah (experimented by Brindley, 1959).

" $\mathrm{B}$ ": Indicates a broad peak, 
(3) The thermobalance curve clearly indicated that the water in this sepiolite is lost as if the dehydration occurred in four temperature regions; and on the differential thermal analysis curve, the low temperature endothermic peak is composed of a double peak and also the endothermic peak in the region of $450^{\circ}-650^{\circ} \mathrm{C}$ is very small and vague, and the high temperature endothermic effect beginning at about $700^{\circ} \mathrm{C}$ is relatively weak. The inversion is not so much remarkable and sharper.

(4) The X-ray diffraction peaks closely agree with those of usual sepiolites in the literature, but in its crystallinity, a much larger variation is found in comparison with those.

(5) The thermal effects between $400^{\circ}$ and $700^{\circ} \mathrm{C}$ on the X-ray spectrograms somewhat differ from those of the fibrous type sepiolites, but they are very different from those of the Oeyama sepiolite.

\section{ACKNOWLEDGEMENTS}

We wish to express our sincere acknowledgements to Professor T. Sudo, Tokyo University of Education, for his valuable advice and suggestions, and also we are indebted to Mr. H. Kodama, Kurosaki Ceramic Company, for his kind help in this work. Further, we are very grateful for the Grant for Scientific Researches from the Ministry of Education in Japan.

\section{REFERENCES}

Bates, T. F. and Comer, J.J. (1959), Further observation on the morphology of chrysotile and halloysite: in Clays and Clay minerals, (A. Swineford, editor), Pergamon Press, 237-248.

Brindley, G.W. (1959), X-ray and electron diffraction data for sepiolite, Am. Mineral. 44, 495-500.

Caillere, S. (1936), Serpentine minerals, Bull. Soc. fran. Miner, 59, 163-326.

Caillere, S. and Henin, S. (1957), The differential thermal investigation of clays, (R. C. Mackenzie, editor), Mineralogical Society, London, Chap. 9, 231-247.

Caillere, S. and Henin, S. (1961), The x-ray identification and crystal structure of clay minerals, (G. Brown, editor), Mineralogical Society, London, Chap. 8, 325-342.

Davis, D.W. Rochow, T.G., Fuller, M.L., Kerr, P.F. and Hamilton, P.K (1950). Electron micrographs of clay minerals, Prelim. Rep. No. 6 of Reference clay minerals, A.P.I. Research Project 49, Am. Petrol. Inst. New York.

Kerr, P.F., Kulp, J. L. and Hamilton, P. K. (1949), Differential thermal 
analysis of reference clay mineral specimens, Prelim. Rep. No. 3 of Reference clay minerals, A. F. I., Research Project 49, Am. Petrol. Inst. New York.

Kinoshita, K., and Takimoto, K. (1939), Oeyama clay nickel deposits, (in Japanese) : Jour. Mining Inst. Kyüshū, 10, No. 8, 1-12.

Martin Vivaldi, J. L. and Cano Ruiz, J. (1956), Effect of heat on sepiolite in Clays and Clay minerals, ( 1 . Swineford, editor), Publication 456, Nat. Sci.-Nat. Res. Coun., Washington, 177-180.

Muchi, M., Hoshino, Y., and Furusato, I. (1965), A poorly-crystallized sepiolite from the Ōeyama nickel mine, Kaya-cho, Yosa-gun, Kyoto Prefecture, Jour. Jap. Assoc. Min. Pet. Econ. Geol., 53, 39-54.

Nagy, B. and Bradley, W. F. (1955), Structure of sepiolite, Am. Mineral. 40, $885-892$.

Preisinger, A. (1959), X-ray study of the structure of sepiolite, in Clays and Clay minerals, (A. Swineford, editor), Pergamon Press, 61-67.

Winchell, A.N. (1951), Elements of optical mineralogy, Part 11, th Ed., 444.

\section{京都府大江山ニッヶル鉱山産の含ニッケルセピオライト}

$\begin{array}{llll}\text { 鞭 } & & \text { 政 } & \text { 共 } \\ \text { 星 } & \text { 野 } & \text { 義 } & \text { 昭 } \\ \text { 古 } & \text { 里 } & & \text { 功 }\end{array}$

摘要

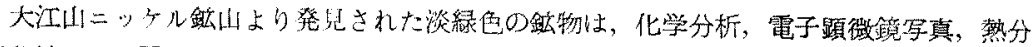

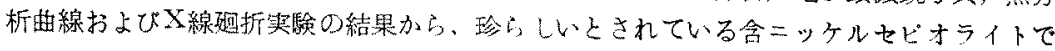
あることが判明した。当鉱山産の含ニッケルセビオライトは，日本で最初に記述されたす のと思われる。その鉱物学的性筫は文献下に示されている瀻維状セビオライトのものと一

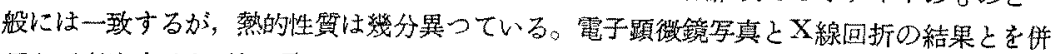
用して考察すると，特に長さの不揃いな繊維状の粒子加ら主としてなつており，大江山産の セビオライトより結晶度は高い。この鉱物の实験式は化学分析の結果, $12 \mathrm{SiO}_{2} \cdot 8(\mathrm{Ni}$,

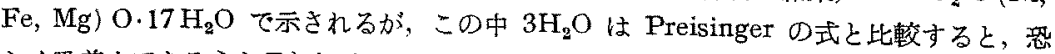
らく吸着水であろうと思われる。 